\title{
Pengaruh Latihan Pendekatan Taktik terhadap Keterampilan Dribbling Peserta Ekstrakurikuler Futsal di Smp Islam Al-Azhar 7 Kota Sukabumi tahun ajaran 2019
}

\section{The Effect Of The Tactical Approach Exercise On The Dribbling Skills Of Extracurricular Participans Is Smp Islam Al-Azhar 7 Kota Sukabumi 2019}

\author{
Gilang Maulidian \\ Universitas Muhammadiyah, Kota Sukabumi, Jawa Barat, Indonesia \\ gilangmaulidian@gmail.com
}

\begin{abstract}
ABSTRAK
Tujuan dilakukannya penelitian ini adalah untuk mengetahui adakah pengaruh dari latihan pendekatan taktik terhadap keterampilan dribbling pada peserta ekstrakurikuler futsal di SMP islma al-azhar 7 kota sukabumi tahun ajaran 2019. Metode penelitian yang digunakan adalah eksperimen dengan instrumen yang digunakan berupa test menggiring bola subagyo irianto, dengan sampel penelitian yang berjumlah 15 orang peserta ekstrakurikuler futsal di SMP islam al-azhar 7 kota sukabumi.

Desaind penelitian yang digunakan adalah one-group pretetst-posttest desaind. Dengan hasill penelitian menunjukan bahwa nilai rata-rata pada tes awal adalah 21,41 dengan simpangan baku 1,02. Sedangkan untuk rata-rata pada tes akhir adalah 17,94 dengan simpangan baku 1,98. Sementara hasil nilai rata-rata dari gain score adalah 3,46 dengan simpangan baku 1,09. Maka dapat disimpulkan bahwa terdapat peningkatan dari tes awal dan tes akhir.

Hasil hipotesis dapat disimpulkan bahwa t-hitung $(12,35)$ lebih besar dari t-tabel $(2,145)$, maka dapat di artikan bahwa Ho ditolak dan Ha diterima. Sehingga dapat disimpulkan bahwa terdapat pengaruh yang signifikan dari latihan pendekatan taktik terhadap keterampilan dribbling pada peserta ekstrakurikuler futsal di SMP islam al-azhar 7 kota sukabumi tahun ajaran 2019.
\end{abstract}

Kata kunci: pendekatan taktik, futsal, dribbling

\section{ABSTRACT}

The purpose of this research is to find out whether there is an effect of practicing tactical approaches to dribbling skills in futsal extracurricular participants in SMP Islm alAzhar 7 kota Sukabumi in academic year 2019 The research method used was an experiment with the instrument used in the form of a test of dribyo subagyo irianto, with up to a total of 15 futsal extracurricular participants in SMP Islam Al-Azhar 7 kota Sukabumi.

The study design used was a one-group pretest-posttest desatnd. With the results of the study showed that the average value on the initial test was 21.41 with a standard deviation of 1.02 while the average for the final test was 17.94 with a standard deviation of 1 , 98. While the results of the average value of the gain score is 3.46 with a standard deviation of 1.09. Then it can be concluded that there is an increase in the initial test and final test. 
The results of the hypothesis can be concluded that $t-g(12,35)$ is greater than $t-y b a$ $(2,145)$, it can be interpreted that Ho is rejected and Ha is accepted. So it can be concluded that there is a significant influence of the tactical approach training on dribbling skills in futsal extracurricular participants in SMP Islam Al-Azhar 7 kota Sukabumi in 2019.

Keywords: Tactic Approach, Futsal, Dribbling

\section{PENDAHULUAN}

Futsal adalah suatu cabang olahraga bola besar yang dimainkan oleh dua tim yang saling berhadapan, olahraga yang dipopulerkan oleh Juan Carlos Ceriani pada tahun 1930 di Montevidio Uruguay, futsal merupakan sebuah singkatan dari bahasa Portugis (Futebol De Salao) atau (Futbol Sala) dalam bahasa Spanyol yang bermakna sama, yaitu sepak bola ruangan.

Ektrakurikuler futsal menjadi yang paling banyak diminati dikalangan murid-murid di hampir semua lembaga pendidikan, di Sukabumi sendiri futsal menjadi olahraga yang paling diminati, banyak nya orang yang menyediakan gedung olahraga untuk futsal sehingga sekolah yang tidak mempunyai lapangan yang memadai tetap bisa melaksanakan ektrakurikuler, namun tentu dengan pengawasan guru maupun pelatih itu sendiri, Tujuan kegiatan Ekstrakurikuler pada umumnya adalah untuk mengembangkan bakat siswa. Dalam ekstrakulikuler juga dimanfaatkan untuk mengisi waktu luang dengan hal yang positif dan mengembangkan bakat yang dimiliki siswa, dengan memilih ekstrakulikuler yang diminati di sekolah diharapkan mampu memberikan prestasi khususnya di bidang olahraga untuk mengharumkan nama sekolah.

Hasil observasi tanggal 25 september dalam pelaksanaan kegiatan ekstrakurikuler futsal dilihat dari latihan dan diperkuat dari pelatih bahwa siswa masih kurang terampil dalam melakukan dribbling. Dalam latihan ekstrakurikuler banyak peserta yang mudah kehilangan bola karena penguasaan bola atau dribbling yang mudah lepas dari penguasaan siswa. karena dribbling sangat diperlukan dalam futsal apalagi disaat terjadi keadaan satu lawan satu antar individu atau permainan suatu tim sudah buntu ketika melakukan penyerangan, sehingga pemain dituntut untuk mempunyai kemampuan dribbling yang baik untuk melewati lawan, mendekat ke sasaran, yang bertujuan agar dapat menciptakan peluang untuk mencetak angka.

Dengan adanya masalah diatas peneliti akan mencoba memecahkan masalah dengan memberikan model latihan yang disesuaikan dengan karakteristik usia mereka disekolah yang bersangkutan, khususnya terhadap keterampilan dribbling para peserta ektrakurikuler futsal, 
peneliti bermaksud ingin melakukan penelitian eksperimen untuk meningkatkan keterampilan dribbling peserta dengan menggunakan latihan pendekatan taktik, dengan menggunakan metode latihan pendekatan taktik diharapkan peserta akan lebih semangat dan termotivasi dan menimbulkan kesenangan pada saat latihan.

Berdasarkan uraian di atas peneliti tertarik melakukan penelitian lebih lanjut mengenai perkembangan prestasi SMP Islam Al Azhar 7 Kota Sukabumi. Dari observasi yang dilakukan peneliti menemukan rumusan masalah yang akan diteliti sebagai berikut: Apakah terdapat pengaruh latihan pendekatan taktik terhadap keterampilan dribling peserta ektrakurikuler futsal di sekolah SMP Islam Al-Azhar 7 Kota Sukabumi 2019?

Dengan adanya rumusan masalah diatas, dan agar penelitian tidak keluar dari jalur yang sudah ditentukan, maka peneliti mencoba untuk membatasi masalah, masalah yang peneliti batasi adalah sebagai berikut:

1. Latihan yang digunakan dalam penelitian ini menggunakan pendekatan taktik.

2. Keterampilan yang dilatih adalah keterampilan menggiring bola.

3. Subjek penelitian hanya pada peserta ekstrakurikuler futsal di SMP islam al-azhar 7 kota sukabumi

Berdasarkan dari rumusan masalah dalam pembahsan sebelumnya, maka tujuan yang ingin digapai peneliti adalah : Untuk mengetahui adakah pengaruh latihan pendekatan taktik terhadapat keterampilan dribling peserta ektrakurikuler futsal di Sekolah SMP Islam AlAzhar 7 Kota Sukabumi 2019.

Hasil dari penelitian ini diharapkan memberikan manfaat bagi semua yang terlibat sekolah maupun peserta ektrakurikuler, baik secara teoritis maupun praktis diantaranya sebagai berikut :

1. Bagi peneliti: dapat mengetahui adakah pengaruh dari latihan pendekatan taktik terhadap keterampilan menggiring bola

2. Untuk pelatih: latihan pendekatan taktik dapat dilakukan agar peserta ekstrakurikuler futsal tidak mudah jenuh

3. Untuk pembaca: dapat dijadikan sebagai bahan referensi melakukan penelitian menggunakan latihan pendekatan taktik.

\section{Pengertian Futsal}

Futsal adalah permainan bola besar yang dimodifikasi dari sepak bola, tujuan permainan futsl sama dengan permainan sepak bola pada umumnya, yaitu untuk memasukan bola ke gawang lawan dengan sebanyak-banyaknya. Dua tim akan saling mencoba untuk 
memasukan bola sabanyak-banyaknya ke dalam gawang musuh dan menjaga gawang sendiri dari kemasukan bola. Pemenang ditentukan jika salah satu dari kedua tim yang berhadapan memasukan bola lebih banyak dari tim satunya. Menurut Sukirno (2010: 1) "Futsal adalah suatu bentuk permainan bola yang dimainkan oleh dua regu atau tim, mempunyai anggota lima orang. Tujuan dari permainan futsal adalah memasukan bola ke gawang lawan sebanyak-banyaknya, dan menjaga gawang sendiri jangan sampai kemasukan bola dari lawan". Menurut Justinus Lhaksana dalam Rudito Adani (2015: 9/10) "Sebelum berkembang menjadi cabang olahraga yang kedudukannya sejajar dengan sepak bola rumput, futsal ditekuni sebagai sarana pengarahan dan pembentukan para pemain muda yang ingin berkarir dalam bidang futsal". Dengan beberapa pendapat akhli di atas maka dapat disimpulkan bahwa futsal adalah suatu permainan sepak bola yang dimodifikasi sehingga menjadi sangat cepat dan juga dinamis, sehingga dapat mengembangkan kemampuan dan kecepatan dalam mengambil suatu keputusan.

\section{Pengertian Dribbling:}

Dribbling adalah salah satu cara untuk dapat menguasai permainan dalam futsal, sekalius menjadi cara untuk dapat melewati pertahanan lawan sehingga lebih mudah untuk menciptakan peluang dan memasukan bola kegawang lawan. Menurut Muhammad Asriady Mulyana (2014: 54) "Menggiring bola atau yang biasa disebut juga dengan Dribbling, yang artinya teknik menguasai bola dengan baik pada saat bola berada dikakinya". Dribbling ( Teknik Dasar Menggiring Bola) adalah suatu cara untuk bisa melewati pemain lawan dan bertujuan untuk mencetak angkat atau memasukan bola ke gawang lawan. Teknik dribbling merupakan keterampilan penting dan mutlak harus dikuasai oleh setiap pemain futsal, Dribbling merupakan kemampuan yang dimiliki pemain dalam menguasai bola sebelum diberikan kepada temannya untuk menciptakan peluang dalam mencetak gol.

\section{Pengertian Pendekatan Taktik}

Pendekatan taktik menurut Yudanto dalam Juni Istanto (2008: 18), "pembelajaran taktik dalam pembelajaran permainan merupakan sebuah pendekatan pembelajaran menekankan pada bermain dan belajar keterampilan teknik dalam situasi bermain”. Melalui bentuk permainan siswa akan lebih senang melakukan sebuah permainan dan dapat dijadikan sarana sebagai untuk bisa mencapai tujuan dalam latihan. Beltasar Tarigan dalam Juni Istanto menyebutkan bahwa (2014: 22), "Latihan melalui pendekatan taktik adalah pembelajaran yang memberikan suatu alternatif yang memberikan kesempatan pada siswa untuk mempelajari keterampilan teknik dalam situasi bermain". 
Berdasarkan beberapa pendapat di atas dapat disimpulkan bahwa latihan pendekatan taktik merupakan cara latihan yang dikemas dalam bentuk permainan untuk mempelajari keterampilan teknik dalam situasi bermain sehingga dapat memenuhi rasa senang anak. Disamping itu, pendekatan taktik dalam pembelajaran permainan memberikan suatu kesempatan kepada siswa untuk mengetahui dan melihat relevansi keterampilan teknik pada situasi bermain yang sesungguhnya.

4. Pengertian Latihan

Latihan adalah suatu cara untuk dapat meningkatkan suatu kemampuan atau keterampilan dalam suatu bidang yang ditekuni oleh seseorang agar dapat mencapai kemampuan maksimalnya

Menurut Ida Bagus Wiguna (2017: 2) "Latihan merupakan sebuah proses yang dilakukan oleh atlet untuk mempersiapkan kondisi terbaik yang mungkin dicapainya". Latihan yang terencana dan terstruktur dapat mengembangkan kemampuan para atlet serta akan menambah kemampuan dirinya untuk mendapatkan kondisi maupun performa yang baik. Sedangkan menurut Harsono dalam Satriya dkk (2014: 12) "Latihan adalah proses yang sistematis dalam berlatih atau bekerja secara berulangulang dengan menambah jumlah hari maupun beban latihan pekerjaanya". Proses latihan tidak akan menjadi sia-sia apabila dibentuk dan di program dengan baik, dengan adanya pelatih yang profesional atlet akan lebih paham dan menikmati proses latihan. Berdasarkan kutipan dari para ahli diatas dapat disimpulkan bahwa latihan adalah suatu proses yang terencana dan terstruktur agar dapat meningkatkan kemampuan diri sesuai minat dan bakat yang diikuti, latihan juga harus dilakukan dengan terus menerus atau dilakukan secara berulang-ulang agar latihan berjalan efektif dan sesuai dengan apa yang di tuju dalam latihan tersebut.

\section{Pengertian Ekstrakurikuler}

Ekstrakurikuler adalah sebagai wadah atau wahana untuk menyalurkan bakat dan minat yang dimiliki olaeh setiap murid disekolah. menurut Asmani (2011: 62) adalah kegiatan pendidikan diluar jam mata pelajaran dan pelayan konseling untuk membantu pengembangan peserta didik sesuai dengan kebutuhan, potensi, bakat, dan minat mereka melalui kegiatan yang secara khusus diselenggarakan oleh pendidik dan atau tenaga kependidikan yang berkemampuan dan berwenang di sekolah.

Kegiatan ekstrakurikuler yang ada di sekolah ini sangat membantu dalam pembentukan karakter peserta didik. Peserta didik menjadi lebih aktif di dalam sekolah ketika waktu belajar mengajar maupun waktu di luar jam pelajaran. Hal ini menjadi hal yang sangat positif dan nilai tersendiri bagi peserta didik. Dapat ditarik kesimpulan bahwa kegiatan 
ekstrakurikuler sebagai wadah bakat siswa untuk dapat mengembangkan kemampuannya, menampung sesuatu yang dibutuhkan oleh siswa untuk lebih berprestasi dan mendapatkan pengalaman belajar di luar jam pelajaran ketika di sekolah. Keberadaan kegiatan ekstrakurikuler sangat berpengaruh dan menguntungkan bagi sekolah, karena siswa dapat meluangkan waktunya untuk mengembangkan kemampuannya sehingga menambah pengalaman dan waktu terpakai oleh hal yang lebih positif di luar jam pelajaran

6. Penelitian Yang Relevan

Hasil penelitian yang relevan dengan penelitian ini sangat diperlukan untuk mendukung kajian teoritis yang telah ditemukan sehingga dapat digunakan sebagai landasan pada kerangka berfikitr. Hasil penelitian sebagai berikut: Penelitian yang berjudul "Pengaruh Latihan Small-sided Games terhadap Keterampilan Dasar Permainan Sepakbola Usia Dini”, oleh Hevi Susanto (2006). Penelitian tersebut bertujuan untuk mengetahui pengaruh metode latihan small-side game terhadap keterampilan dasar permainan sepakbola siswa SSB Selabora Puspor UNY yang berjumlah 20 orang. Instrument dan satuan pengukuran yang digunakan saat pretest dan posttest adalah The David Lee Soccer Potetial Circuit Test. Dari hasil perhitungan yang diperoleh bahwa nilai t hitung $=4,094>\mathrm{t}$ tabel $(0,05.19)=2,093$ berati terdapat perbedaan yang signifikan. Hasil ini menunjukkan terdapat pengaruh metode small-side games terhadap keterampilan dasar permainan Sepak Bola.

\section{Hipotesis}

Menurut Sugiyono (2017: 63) menyampaikan bahwa hipotesis yaitu: "Hipotesis merupakan jawaban atau dugaan sementara terhadap rumusan masalah penelitian, dimana rumusan masalah penelitian telah dinyatakan dalam bentuk kalimat pertanyaan". Adapaun hipotesis yang diajukan penulis terhadap penelitiannya adalah sebagai berikut: Terdapat pengaruh yang signifikan dari latihan pendekatan taktik terhadap keterampilan dribbling peserta ekstrakurikuler di SMP Islam Al-Azhar 7 Kota Sukabumi.

\section{METODE PENELITIAN}

Menurut Sugiyono (2018: 2). "Metode penelitian pada dasarnya merupakan cara ilmiah untuk mendapatkan data dengan tujuan dan penggunaan tertentu, cara ilmiah, data, tujuan, dan kegunaan merupakan kata kunci dalam melakukan metode pada penelitian" Setiap penelitian memerlukan suatu metode yang sesuai dengan masalah dan tujuan dari penelitian, hal tersebut menyimpulkan bahwa metode penelitian berada dalam kedudukan yang penting dalam pelaksanaan pengumpula data. 
Beberapa metode penelitian yang biasa digunakan yaitu historis, deskriptif, R\&D serta Eksperimen. Untuk menyesuaikan dengan masalah yang akan dikaji, peneliti akan menggunankan metode penelitian berupa Eksperimen, metode ini digunakan untuk mengetahui pengaruh dari suatu perlakuan tertentu yang diberikan terhadap peserta yang akan diteliti, maka sesuai dengan metode penelitian tersebut, peneliti akan mencari tau seberapa besar dampak yang ada terhadap objek yang dekenainya dengan cara memberikan suatu perlakuan khusus.

Variabel menurut Sugiyono (2009:38) adalah "Segala sesuatu yang berbentuk apa saja yang ditetapkan oleh peneliti untuk dipelajari sehingga diperoleh informasi tentang hal tersebut, kemudian ditarik kesimpulannya". Variabel penelitian yang digunakan dalam penelitian ini meliputi: variabel penelitian yang mempengaruhi (latihan pendekatan taktik) dan variabel akibat (keterampilan dribbling). Variabel yang mempengaruhi disebut variabel penyebab atau variabel bebas $(\mathrm{X})$, sedangkan variabel akibat disebut variabel tak bebas atau variabel terikat $(\mathrm{Y})$.

Variabel bebas yang dimaksud adalah Latihan pendekatan taktik yang dimaksud dalam penelitian ini adalah bentuk latihan yang dikemas dalam bentuk permainan kecil seperti 3 lawan 3 dengan fokus dan tujuan latihan yang sudah ditentukan untuk meningkatkan kesadaran siswa tentang konsep bermain melalui penerapan teknik dalam situasi permainan sesungguhnya. Sementara variabel terikat yang dimaksud adalah Keterampilan menggiring bola yang dimaksud dalam penelitian ini adalah kemampuan menggiring bola siswa ekstrakurikuler futsal di SMP Islam Al-Azhar 7 kota sukabumi dalam melewati beberapa rintangan. Pengukuran keterampilan menggiring bola dalam penelitian ini dilakukan dengan tes keterampilan menggiring bola.

Dalam suatu penelitian harus meneliti yang sesuai dengan variable-variabel yang terkandung dalam tujuan pada hipotesis penelitian, penelitian yang dilakukan adalah sebuah eksperimen one groups pretest-posttest design yaitu sebuah eksperimen yang hanya melibatkan satu kelompok yang diteliti tanpa melibatkan kelompok lain untuk dijadikan perbandingan.

Dalam suatu penelitian dibutuhkan alat yang dipakai untuk mengumpulkan data. Menurut Sugiyono (2009: 133) instrumen penelitian digunakan untuk mengukur nilai variabel yang diteliti. Syarat tes yang baik adalah memiliki validitas dan realibilitas. Instrumen merupakan alat ukur untuk mendapatkan data agar suatu penelitian mendapatkan data yang sesuai diharapkan untuk itu dibutuhkan instrumen yang dirancang dan dibuat 
sedimikian rupa. Dalam penelitian ini instrumen yang digunakan mengacu pada variabel bebas dan variabel terikat. Adapun variabel bebas yaitu latihan pendekatan taktik sedangkan variabel terikat yaitu keterampilan dribbling bola. instrumen yang digunakan yaitu tes kemampuan menggiring bola dari Subagyo Irianto yang diberi nama menggiring bola secara zig-zag (dengan validitas tes 0,559 dan reliabilitas tes 0,637). Tes ini digunakan untuk mengukur kecakapan menggiring bola.

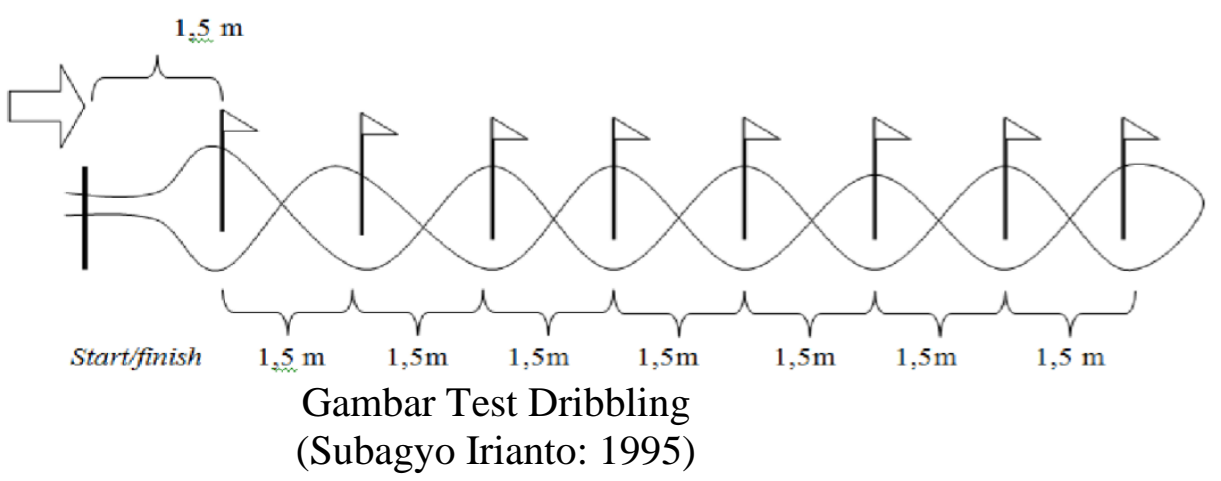

Sampel adalah bagian dari populasi penelitian yang akan diambil. Dengan Jumlah populasi yang berjumlah 15 orang, maka dari itu teknik sampling yang akan digunakan yaitu teknik sampling jenuh atau total sampling, dimana teknik sampling ini diharuskan mengikutsertakan seluruh peserta yang ada dalam populasi. Dikatakan oleh Sugiyono (2017: 85) "Teknik sampling jenuh adalah teknik sampling bila semua anggota populasi digunakan sebagai sampel, hal ini sering dilakukan bila jumlah populasi relatif kecil atau kurang dari 30 orang, atau penelitian yang ingin membuat gneralisasi dengan kesalahan yang sangat kecil". Dengan ini maka hanya akan dibuat 1 kelompok penelitian saja dengan melibatkan semua anggota ekstrakurikuler futsal di SMP Islam Al-Azhar 7 Kota Sukabumi.

Dalam pengambilan data, sebelumnya peneliti menyiapkan sarana dan prasarana yang dibutuhkan dalam pelaksanaan tes terlebih dahulu, kemudian membariskan siswa untuk berdoa dilanjutkan presensi, selanjutnya siswa melakukan pemanasan selama 15 menit, setelah itu peneliti memberikan petunjuk pelaksanaan tes yang akan dilaksanakan. Pengumpulan data yang akan dilakukan yaitu dengan cara test, test dilakukan untuk mendaptakan data secara langsung menggunakan test dribbling bola. Test akan dilakukan dua kali yaitu pretest dan posttest. 


\section{HASIL DAN PEMBAHASAN}

\section{Pembahasan}

Penelitian ini dilakukan untuk meningkatkan Ketarampilan Dribbling menggunakan program latihan pendekatan taktik, dimana latihan sangatlah dibutuhkan untuk dapat meningkatkan teknik dasar keterampilan dribbling. Penelitian ini dilakukan pada peserta Ekstrakurikuler futsal di SMP islam al-azhar 7 kota Sukabumi. Peneliti mengambil data berupa penilaian terhadap keterampilan dribbling siswa yang mengikuti Ekstrakurikuler futsal, dengan jumlah populasi sebanyak 15 orang dan semua populasi diambil sebagai sampel. Metode penelitian yang digunakan berupa Eksperimen dengan menggunakan desaind one group pretest-posttest. Desain ini mermerlukan tiga tahapan yaitu pretest (tes awal), treatment (perlakuan) dan posttest (tes akhir). Pretest dilaksanakan pada bulan desember 2019, dan postest dilaksanakan pada bulan januari 2020. Berdasarkan masalah yang peneliti temukan di Ekstrakurikuler futsal di SMP Islam al-azhar 7 kota sukabumi 2019, yaitu keterampilan dribbling pada peserta Ekstrakurikuler futsal belum bisa disebut baik, maka dengan adanya permasalahan tersebut peneliti memustuskan untuk mengadakan penelitian, penelitian dilakukan dengan harapan dapat meningkatkan keterampilan dribbling pada peserta ekstrakurikuler futsal di SMP Islam al-azhar 7 kota sukabumi 2019 tersebut, dengan menggunakan latihan pendekatan taktik sesuai dengan program latihan yang peneliti berikan. Setelah peneliti mengolah data yang di dapatkan dari hasil pretest dan posttest yang dilakukan, dapat disimpulkan bahwa dari latihan pendekatan taktik yang peneliti berikan, terdapat pengaruh pada keterampilan dribbling para peserta ekstrakurikuler di SMP Islam alazhar 7 kota sukabumi tahun ajaran 2019. Untuk mengetahui ada tidaknya pengaruh dari latihan pendekatan taktik terhadap keterampilan dribbling peserta ekstrakurikuler futsal di SMP Islam al-azhar 7 kota sukabumi tahun ajaran 2019 dengan melakukan uji-t.

Uji-t dapat mengetahui besar nilai t-hitung dan signifikannya. Ada tidaknya pengaruh yang signifikan dari pengaruh latihan pendekatan taktik terhadap keterampilan dribbling peserta ekstrakurikuler futsal SMP Islam al-azhar 7 kota sukabumi tahun ajaran 2019 diketahui dari nilai rata-rata pretest dan posttest pada uji-t tersebut. Berdasarkan hasil perhitungan uji-t menunjukan adanya pengaruh yang signifikan yang diberikan dari latihan pendekatan taktik terhadap keterampilan dribbling pada peserta ekstrakurikuler futsal di SMP Islam al-azhar 7 kota sukabumi tahun ajaran 2019. Dibuktikan dengan t-hitung sebesar 12,35 $>$ t-tabel 2,145. Setelah dilakukan penelitian dari awal penelitian atau sampai dengan dilaksanakannya test akhir, perlu adanya tindak lanjut dari lembaga ataupun pihak yang bersangkutan supaya keterampilan dribbling yang dimiliki para siswa ekstrakurikuler 
semakin meningkat. Berdasarkan pengamatan dari hasil penelitian yang peneliti laksanakan, maka rangkuman sementara sebagai berikut:

1. Keterampilan dribbling sangat penting bagi para pemain futsal, karna dribbling adalah salah satu teknik yang sangat bermanfaat pada saat pertandingan.

2. Terdapat pengaruh yang signifikan dari latihan pendekatan taktik terhadap keterampilan dribbling para peserta ekstrakurikuler.

3. Dengan program latihan yang baik, terstruktur dan terencana dapat membantu dalam tercapainya tujuan dari latihan.

\section{Hasil}

Deskripsi ini ditujukan agar lebih mudah dalam pembacann data dari penelitian. Deskripsi data penelitian diambil dari hasil pretest dan posttest yang telah dilaksanakan. Tabel dibawah menunjukan hasil rata-rata dan simpangan baku dari hasil pretest dribbling adalah sebesar 21,41 dengan simpangan baku sebesar 1,02

Tabel Rata-Rata \& Simpangan Baku Pretest

\begin{tabular}{|l|l|l|}
\hline & Rata-rata (pretest) & Simpangan baku \\
\hline Dribbling & 21,41 & 1,02 \\
\hline
\end{tabular}

Tabel dibawah menunjukan hasil rata-rata dan simpangan baku dari hasil posttest dribbling adalah sebesar 17,94 dengan simpangan baku sebesar 1,98 Tabel dibawah menunjukan hasil rata-rata dan simpangan baku dari hasil posttest dribbling adalah sebesar 17,94 dengan simpangan baku sebesar 1,98

Tabel Rata-Rata \& Simpangan Baku Posttest

\begin{tabular}{|c|c|c|}
\hline & Rata-rata posttest & Simpangan baku \\
\hline Dribbling & 17,94 & 1,98 \\
\hline
\end{tabular}

Tabel dibawah menunjukkan rata-rata gain score sebesar 3,46. dan simpangan baku sebesar 1,09

Tabel Rata-Rata \& Simpangan Baku Gain Score

\begin{tabular}{|c|c|c|}
\hline & Rata-rata gain score & Simpangan baku \\
\hline Dribbling & 3,46 & 1,09 \\
\hline
\end{tabular}

Setelah nilai rata-rata dan simpangan baku diketahui, maka langkah selanjutnya adalah melakukan tes uji normalitas menggunakan uji normalitas liliefors. Tes ini dilakukan untuk menguji jika data berdistribusi normal.

Tabel Uji Normalitas 


\begin{tabular}{|l|l|l|l|l|}
\hline & Lo pretest & Lo posttest & L tabel & Kesimpulan \\
\hline Dribbling & 0,220 & 0,0796 & 0,227 & Normal \\
\hline
\end{tabular}

Berdasarkan tabel diatas dapat diketahui bahwa nilai $\mathrm{L}$ dari daftar $=0,227$ sedangkan nilai $\mathrm{L}_{0}$ kelompok latihan pendekatan taktik pretest $=0,220$ dan posttest $=0,0796$ kesimpulannya adalah data diatas berdistribusi normal karena di bawah nilai dari $\mathrm{L}_{\text {tabel. }}$

Tindakan elanjutnya melakukan uji homogenitas yang bertujuan mengetahui nilai diatas bersifat homogen atau tidak.

Tabel Uji Homogenitas

\begin{tabular}{|c|c|c|c|}
\hline & $F_{\text {hitung }}$ & $\mathrm{f}_{\text {tabel }}$ & Keterangan \\
\hline Dribbling & 1,941 & 2,48 & Homogen \\
\hline
\end{tabular}

Atas dasar hasil pengujian kesamaan dua variansi diatas, diketahui bahwa hasil F- hitung 1,941 yang lebih kecil dari F-tabel=2,58 dengan taraf signifikasnsi $\alpha=0,05$. Kesimpulan dari hasil pengujian kedua tes sampel homogen.

Setelah data terbukti berdistribusi normal dan homogen, maka langkah selanjutnya adalah melakukan uji analisis data terhadap kelompok data sampel (pengujian data analisis ini untuk mengetahui apakah terdapat peningkatan hasil latihan yang signifikan). Hasil analisis statistika dapat dilihat pada tabel berikut ini:

Tabel Uji Signifikan

\begin{tabular}{|l|c|c|c|}
\hline & T hitung & T tabel & Signifikan \\
\hline Dribbling & 12,35 & 2,145 & Signifikan \\
\hline
\end{tabular}

Dari hasil pengujian diperoleh bahwa t- hitung $=12,35$ yang lebih besar dari $\mathrm{t}$ - tabel pada tingkat signifikansi $=0,05$ dengan $\mathrm{dk}(\mathrm{n} 1-1)=14$ data dari distribusi $\mathrm{t}$ diperoleh $=2,145$. Pengujiannya adalah Ho jika>t- $\alpha$ maka t-hitung berada di daerah penolakan $\mathrm{H}_{0}$, jadi $\mathrm{H}_{0}$ ditolak dan Ha diterima. Kesimpulannya latihan pendekatan taktik memberikan pengaruh yang signifikan terhadap peningkatan keterampilan dribbling dalam permainan futsal

\section{KESIMPULAN}

Berdasarkan dari hasil penelitian dan pengolahan data yang peneliti laksanakan mengenai pengaruh latihan pendekatan taktik terhadap keterampilan dribbling peserta ekstrakurikuler futsal di SMP Islam al-azhar 7 kota sukabumi tahun ajaran 2019, dapat disimpulkan bahwa Terdapat pengaruh latihan pendekaktan taktik terhadap keterampilan dribbling peserta ekstrakurikuler futsal di SMP Islam al-azhar 7 kota sukabumi tahun ajaran 2019, hal ini dibuktikan dari hasil nilai rata-rata yang diperoleh ketika melakukan pretest 
adalah 21,41 dan simpangan baku 1,02. Sedangkan hasil dari posttest dengan nilai rata-rata 17,94 dan simpangan baku 1,98 dan hasil gain score adalah nilai rata-rata 3,46 dan dengan simpangan baku 1,09. Maka dapat ditarik kesimpulan bahwa adanya peningkatan dari pretest dan posttest. Hasil hipotesis dapat disimpulkan bahwa t-hitung $(12,35)>\mathrm{t}$-tabel $(2,145)$ maka $\mathrm{H}_{\mathrm{o}}$ di tolak.

Dengan ditentukannya hasil dari penelitian, peneliti mengajukan beberapa saran dan masukan yang dapat dipertimbangkan oleh pihak yang bersangkutan, yaitu :

1. Dengan diadakannya penelitian yang dilakukan peneliti, diharapkan pihak dari SMP Islam al-azhar 7 kota sukabumi lebih memperhatikan ekstrakurikuler yang ada khususnya futsal untuk berperan lebih aktif serta dapat menjadi tempat penyaluran minat dan bakat bagi peserta didik.

2. Bagi peserta ekstrakurikuler maupun siswa yang lain dengan adanya bentuk latihan kelincahan ini dapat meningkatkan keterampilan dribbling dan memotivasi peserta yang lain untuk meningkatkan kemampuan dribbling nya.

\section{DAFTAR PUSTAKA}

Bagus W, I. (2017). Teori dan Aplikasi Latihan Kondisi Fisik. Depok: PT RajaGrafindo Persada

Istanto J. (2014). Keterampilan Dribbling Bola Siswa Ekstrakurikuler Sepakbola Di Sma Negeri 4 Purworejo. Skripsi. Fakultas Ilmu Keolahragaan. Universitas Negeri Yogyakarta: Yogyakarta. Tidak Diterbitkan.

Mulyono, M. A. (2014). Buku Pintar Panduan Futsal. (S. Wahyuni \& A. Latif, Eds.). Jakarta Timur.

Rudito A. (2015). Pengaruh Latihan Small-Side Game Terhadap Akurasi Passing Mendatar Siswa Di Ekstrakurikuler Futsal MTS Mu'allimin Muhammadiyah Yogyakarta. Skripsi. Fakultas Ilmu Keolahragaan. Unuversitas Negeri Yogyakarta: Tidak Diterbitkan.

Satriya, Dikdik Z.S, I Imanudin. (2014). Teori Latihan Olahraga. Bandung: CV Nurani.

Sugiyono. (2018). Metode Penelitian Kuantitatif, Kualitatif, Dan R\&D (27th Ed.). Bandung: Alfabeta, CV

Sukirno. (2010). Belajar Bermain Futsal (2nd Ed.). Depok: CV Arya Duta. 